\title{
Silva, Rafael Viana da Elementos inflamáveis: \\ organizações e militância anarquista no Rio de Janeiro e São Paulo (1945-1964)
}

Kauan Willian dos Santos*

Curitiba: Prismas, 2017. 338p.

Uma visão clássica do anarquismo no Brasil e em algumas partes do mundo afirma que essa corrente política, predominante no movimento operário nas primeiras décadas do século XX, apresentou declínio evidente após 1920, sofrendo sua derrota em nosso país na Era Vargas, com suas mudanças no mundo sindical. Nas análises de certos militantes que buscam legitimar outras propostas de transformação, o anarquismo seria um movimento prematuro, com a ausência de alianças concretas e apresentando um projeto falho para a sociedade. Enquanto isso, para um número significativo de pesquisas atentas ao mundo do trabalho, reverberando em parte tal visão, o anarquismo quase desapareceu desde então e não apresentou grande influência para o movimento operário, principalmente depois da segunda metade do século XX.

Buscando rebater e relativizar tais visões temos em mãos Elementos inflamáveis, livro ligeiramente modificado da dissertação de mestrado de Rafael Viana da Silva, defendida em 2014 no programa de pós-graduação em História da Universidade Federal Rural do Rio de Janeiro (UFRRJ). Aproveitando pesquisas recentes e também proeminentes que já apontaram a resistência dos anarquistas, seja no âmbito cultural ou sindical, durante os anos de $1930 \mathrm{e}$ 1945, o autor tenciona mostrar a reorganização do anarquismo durante a chamada redemocratização, entre os anos 1945 e 1964. Sem ignorar o contexto para tal, Silva mostra como, em meio à crise do Estado Novo, os anarquistas vão aproveitar brechas para se organizarem de forma mais sistemática e tentarem aumentar sua influência entre as classes populares, assim como incrementar suas fileiras militantes, fato que se deu nas cidades de São Paulo e Rio de Janeiro e, em certa medida, no estado do Rio Grande do Sul.

\footnotetext{
* Doutorando em História Social. Faculdade de Filosofia, Letras e Ciências Humanas (FFLCH), Universidade de São Paulo (USP). São Paulo, SP, Brasil. kauanwillian@usp.br
} 
Entre as primeiras atitudes dos adeptos da bandeira negra esteve a criação e a reativação de seus periódicos. Entre eles cita-se o Remodelações, que circulou entre 1945 e 1947 e era coordenado pelos militantes cearenses Moacir Caminha e Maria Iêda, contando também com militantes clássicos como José Oiticica. Em 1947 foi relançado o periódico A Plebe, um dos mais importantes para o anarquismo anos atrás e também essencial para a nova aproximação com as demandas sindicais. Outro importante órgão para a difusão da cultura política anarquista foi o Ação Direta, essencial para as propostas de organização interna do movimento.

Nesse último sentido surgem as primeiras contribuições importantes de Rafael Silva para o tema. Com a aproximação de diferentes gerações militantes concluiu-se em seus debates ser inadmissível ver as estratégias anarquistas como imóveis e imutáveis - era necessário encaixar as demandas libertárias aos novos condicionamentos. Esses militantes referiam-se principalmente à ausência de organização política entre os anarquistas durante as primeiras décadas do século XX, que seria uma das causas, nessa visão, da perda de suas influências. Os anarquistas brasileiros, diferentemente do que se observou em outros países, não conseguiram efetivar suas propostas de organização interna, chamadas de alianças ou partidos, que se protegeriam em momentos de refluxo e também garantiriam certa homogeneidade em suas práticas. Estando os anarquistas enraizados profunda e quase exclusivamente no movimento sindical, este quando foi transformado na década de 1930 garantiu o declínio da estratégia do sindicalismo revolucionário e da consequente influência anarquista, restando apenas seus grupos de afinidade dispersos para a continuação de suas propostas, perdendo assim o contato com os trabalhadores. Na perspectiva dos militantes anarquistas entre 1945 e 1964, portanto, antes de tudo era necessário se organizar politicamente e então garantir formas e estratégias diversas para recuperar esse e outros contatos.

Seguindo esse debate, Silva examina na primeira parte do livro as discussões e dilemas internos do anarquismo. No primeiro capítulo dessa seção, evidencia-se a importância da participação dos militantes em congressos internacionais, absorvendo e disseminando experiências transnacionais para o anarquismo em nível global. O autor segue analisando os congressos anarquistas no país, em 1948, 1953, 1959 e 1963, essenciais para a reorganização do movimento. No terceiro capítulo, debate-se a retomada da estratégia do sindicalismo revolucionário no papel da transformação da realidade para os anarquistas no período. Nesse sentido, longe de se ater principalmente a propostas culturais como se imaginou, a intentona majoritária anarquista continuou 
sendo, ao menos até 1959, o sindicalismo e o movimento operário, onde seus militantes dispensaram numerosas energias (p.182).

Percebemos que as principais referências metodológicas do livro nessa parte são os autores que desenvolvem as concepções de cultura política como Serge Berstein, já que é importante, para Rafael Silva, perceber o desenvolvimento do anarquismo dentro de suas próprias referências, da sua família política, suas leituras e dilemas. Já na segunda parte da obra o autor analisa como tais estratégias foram absorvidas e articuladas no movimento operário, em meio aos trabalhadores e, também, aos grupos militantes de outras vertentes ideológicas. Por isso, decide utilizar como referência Edward Palmer Thompson, inspirado nos estudos que mostram as ideologias e práticas como não estanques aos comportamentos de classe.

Seguindo essa tendência, no quarto capítulo, primeiro dessa seção, evidencia-se o importante papel dos jornais e impressos também para disseminar a influência do anarquismo e de seus debates externos com outras correntes políticas, assim como em sua adaptação ao contexto. Nesse sentido, até mesmo a forma de venda ou doação desses periódicos foi importante, como numa banca de jornais em frente ao posto de trabalho da Light.

No quinto capítulo, Silva adentra com mais profundidade as relações e articulações políticas dos anarquistas em âmbito internacional e nacional. $\mathrm{Na}$ primeira parte, além de ver suas influências e ligações com a Federação Anarquista Ibérica (FAI) e a Solidariedade Internacional Antifascista (SIA), evidencia-se a recepção dos anarquistas aos imigrantes, principalmente saídos das ditaduras de Franco e Salazar, alguns com experiências na Revolução Espanhola. Esse contato foi essencial para a reformulação de estratégias e táticas e para alavancar o próprio movimento anarquista no país. Após isso, o autor nos mostra os embates no anarquismo com o Partido Comunista Brasileiro, principal força de esquerda do período. A principal crítica dos libertários ao partido se referia exatamente às posições do sindicalismo - os primeiros eram contrários a disputar a estrutura corporativista desses espaços, propondo novos organismos e frentes que respondessem aos interesses dos trabalhadores fora de um ambiente supostamente impregnado pelos mecanismos da classe dominante. $\mathrm{O}$ autor discorda da historiografia que viu os trabalhadores e militantes desse período como estagnados, presos à estrutura e aos condicionamentos do período, mas também rebate a corrente que afirma total liberdade e agência dos personagens em torno do sindicalismo do período. Sua posição é a de que os trabalhadores, de fato, negociavam e barganhavam em meio às regras do sindicalismo e da política do período, mas também, por 
vezes, se sentiam pressionados a essa estrutura e, além de não conseguirem alcançar seus alvos, também decidiam lutar recorrendo a outros instrumentos.

Esse debate se estende ao último capítulo da obra, no qual o autor adentra a inserção social do anarquismo. Na primeira parte, Rafael Silva analisa como as estratégias sindicais dos anarquistas foram recebidas e efetuadas na prática. Os anarquistas conseguiam dialogar com os marxistas críticos do stalinismo e sindicalistas independentes criando o Grupo de Orientação Sindical dos Trabalhadores da Light e deixando uma influência visível no Sindicato dos Trabalhadores Gráficos, também de caráter combativo, convergindo, posteriormente, para a criação do Movimento de Orientação Sindical (MOS). A inserção libertária nesses ambientes garantiu posições nas manifestações importantes no período, como a greve dos 400 mil em 1957. Na última parte da obra, o autor mostra como as ações culturais dos anarquistas eram mediadas entre as culturas de classe dos trabalhadores e dos grupos subalternos, ainda os principais alvos do anarquismo. Nesse sentido, mostra-se a importância de espaços como o Centro de Cultura Social para a formação de novos militantes e de trabalhadores, principalmente informais. Os periódicos também foram importantes para a criação de centros de cultura e estudos, poemas e debates públicos, inserção que se dava muito fortemente entre os estudantes universitários. As táticas educativas e o apoio às ações culturais nesse período foram importantes para garantir um lugar a partir do início da década de 1960, quando os militantes libertários deixavam aos poucos os ambientes estritamente sindicais, interpretando que gastavam muita energia para barrarem o reformismo e a disputa com outras tendências de esquerda. $\mathrm{O}$ apoio a outros ambientes, dessa vez discutidos e minimamente organizados nos congressos citados, garantiu a sobrevivência mínima do anarquismo nas décadas posteriores, durante a Ditadura Militar, quando os anarquistas enfrentaram outros dilemas.

Tudo isso torna o livro de Rafael Viana da Silva uma importante contribuição a um período não muito estudado, inclusive entre os próprios anarquistas contemporâneos, que preferem visualizar o anarquismo áureo a se ater em épocas nas quais foi mais difícil implementar e articular suas estratégias. Ainda assim, aprendemos que quando o anarquismo não foi um elemento explosivo, certamente foi um elemento inflamável.

Resenha recebida em 4 de maio de 2017. Aprovada em 5 de junho de 2017. 